\title{
SELF-REGULATION OF ELECTRONIC COMMERCE: ISSUES IN THE CONTEXT OF CHILEAN LAW
}

\section{LA AUTORREGULACIÓN DEL COMERCIO ELECTRÓNICO: APRECIACIONES DESDE EL DERECHO CHILENO}

\author{
DAVID LÓPEZ JIMÉNEZ* \\ Antonio J. Monroy Antón** \\ JAMES CRICHLOW***
}

\begin{abstract}
Nowadays, electronic commerce is a booming contractual activity. Indeed, empirical data shows that it is increasing internationally. However, it is failing to establish itself for various reasons. In fact, due mainly to the surrounding distrust, it is yet to reach a similar level to physical or traditional contracting. Self-regulatory systems have been created to mitigate this handicap. Providers operating on the internet can voluntarily adhere to these systems. If they do, differentiating themselves positively from their competitors, they will have to comply with good practices established in the code of conduct. In this paper, we will analyze the peculiarities that arise in this regard from the perspective of Chilean Law.
\end{abstract}

Key words: Self-regulation; electronic commerce; Internet; advertising; transactions.

RESUMEN: El comercio electrónico constituye, en la actualidad, una actividad contractual en auge. En efecto, los datos empíricos ponen de manifiesto que, a nivel internacional, se está incrementando. Ahora bien, por diversos factores, no llega a consolidarse. En efecto, debido sobre todo a la desconfianza que en torno al mismo se genera, no alcanza un nivel similar a la contratación física o tradicional. Para mitigar tal hándicap, se idearon los sistemas de autorregulación. Los proveedores que operan en Internet pueden voluntariamente adherirse a los mismos. En el supuesto de que lo hagan, diferenciándose positivamente frente a sus competidores, tendrán que observar las buenas prácticas establecidas en el código de conducta. En el presente artículo analizaremos las particularidades que, desde la perspectiva del Derecho chileno, se plantean en este sentido.

Palabras clave: Autorregulación; comercio electrónico; Internet; publicidad; transacciones.

\footnotetext{
* PhD (with European mention), Universidad de Sevilla (Spain), and PhD, Universidad Rey Juan Carlos (Spain). Research professor at the EAE Business School. Postal address: Joaquín Costa, 41, 28002 Madrid, Spain. E-mail: dlopezjimenez@gmail.com.

** PhD (with European mention), Universidad Politécnica de Madrid (Spain), and PhD, Universidad de Huelva (Spain). Research professor at the Universidad de Valladolid, Spain. Postal address: Avda. Filipinas 16, Madrid, Spain. E-mail: amonroy111@hotmail.com.

*** MA from the University of Alcalá (Spain). Research professor at the Cardenal Cisneros University College (Madrid, Spain). Postal address: Av. de los Jesuitas, 34, Madrid, Spain. E-mail:james.crichlow@cardenalcisneros.es.
}

This work is part of the Research Project FONDECYT N 11130188, directed by David López Jiménez. 


\section{INTRODUCTION}

Recent decades have witnessed a significant evolution of new technology. The pace at which they advance is simply unstoppable. These interesting technical innovations facilitate our daily activities, yet they also pose potential hazards ${ }^{1}$. As with any aspect of the prevailing social reality, they are unquestionably under the rule of law.

Just as social life is inconceivable without law, it is not admissible to develop new technologies without self-regulation. It is also predictable that the society of tomorrow will have different needs, structures and values than today.

However, the law always lags behind social reality. The facts tend to move ahead of the legislators, something that is even more evident in the field of interest under examination. Lawyers are dragged along or "pushed" by the facts. However, they always find themselves behind or in pursuit of the latest developments which, while innovating social reality, make the Law increasingly more outdated.

When any legal standard directly or indirectly governs aspects related to new technologies, it must not regulate cases linked to them with an excessive degree of casuistry. The reason is that the legal standard could become obsolete within a short period of time, and consequently unsuitable for its initially conceived purpose.

Regarding possible instruments that exist in order to avoid regulations becoming obsolete quickly, it is important to mention the phenomenon of self-regulation. Among the contexts in which self-regulation operates, the area of new technologies must be highlighted $^{2}$. The field of electronic commerce also occupies a prime position ${ }^{3}$.

Electronic commerce is a prospering contractual activity. Current and future figures, both in Latin America ${ }^{4}$, in general, and in Chile ${ }^{5}$, in particular, allow us to be especially optimistic. We believe that, for this new channel of distribution of goods and services to reach a significant amount, it is imperative to properly legislate the virtual environment ${ }^{6}$ and to develop self-regulatory initiatives.

It should not be ignored that, in the case of a contract made by virtual means, general contract theory ${ }^{7}$ is fully applicable. Although the method is novel, the issuing and

\footnotetext{
Pinochet (2001) p. 469.

2 Regarding the utility of self-regulation rules, AMBLARD (2004) p. 243.

3 Regarding EDI (e-commerce data exchange) as e-commerce origin, CARRASCO (2000) p. 111.

4 In this sense, eMarketer considers that in 2015 e-commerce transactions in Latin America will increase by $24,2 \%$, reaching 88 billion USD. In any case, it will not be the same in all countries. In fact, Brazil and Mexico will be the main in Latin America, with sales of 31.9 and 17, 5 billion, respectively.

5 In the case of Chile, for 2015, e-commerce transactions are expected to grow by approximately 15-20\%, reaching 2, 3 billion USD. Nowadays, $70 \%$ of the population in this country use Internet, which means more than 13 million people. Out of those, 3, 5 million use Internet to purchase.

6 There is not a complete and independent regulation in Chile in this issue, but there are some rules such as Law No 19799 about e-documents, e-signature and other services, and Law No 19496. For the first one, FERNÁNDEZ (2004) pp. 137-167.

7 In Chile there is no special regulation for Electronic contracts. However, Law No 19496 regulates some issues such as pre-contract duties of information or electronic contracts.
} 
acceptance of offers responds to already known legal concepts ${ }^{8}$. In this article, we will pay special attention to $\mathrm{B} 2 \mathrm{C}$ e-commerce, i.e. between businessmen and consumers, which in the case of Chile, holds a position of prominence in Latin America. However, it can also take place between businessmen (B2B). In fact, although it may seem paradoxical, the latter is the predominant type?

The present research study begins with the pre-contractual information duties in which the phenomenon of self-discipline plays a remarkable value. Particularly significant is the relationship that the subject holds with the principle of good faith. In any case, the core of the analysis is devoted to the phenomenon of self-regulation. In this regard, several aspects are studied independently, such as: concept and characters; budgets with which self-discipline systems must comply; possible legal status they deserve; and the consequences of failure.

\section{PRE-CONTRACTUAL INFORMATION DUTIES IN THE AREA OF E-COMMERCE: THE ROLE OF SELF-REGULATION}

Electronic trading is characterized by a high degree of asymmetric information ${ }^{10}$ and a low level of interaction between consumers and traders. All this affects both the conditions and the terms on which the transaction takes place. In order to solve this handicap, the actors in this scenario devised instruments of self-discipline. The latter are notably linked to the pre-contractual information duties. Also, they have a close relationship with good faith.

In distance contracts ${ }^{11}$, including electronic contracts, consumers suffer from a lack of information, as they are only aware of the goods and/or services offered by the commercial presentation made by the businessman or professional in catalogs, television images or websites ${ }^{12}$. This lack of information arises from the fact that the offer reaches the consumer from outside of the normal contract channels. Therefore, there is an asymmetrical contractual relationship, where the consent of both parties (professional and consumer) is not comparable in any way ${ }^{13}$.

\section{PReVIOUS CONSIDERATIONS: THE PRINCIPLE OF PARTY AUTONOMY}

In terms of party autonomy ${ }^{14}$ (or legal freedom ${ }^{15}$ ) in the field of contracts, it refers not only to a freely formed will deciding to subject oneself to a particular contractual

\footnotetext{
8 Pinochet (2013) p. 266.

9 In fact, most of the e-commerce income comes from the B2B. The UNCTAD considers that B2B World income in 2013 reached 15.2 USD billion, while B2C reached 1.2 USD billions.

10 Barrientos (2012) p. 219.

11 For the difference between distance and Electronic contracts, PinOchet (2007) p. 200.

12 Sandoval (2001) p. 169, thinks that this is a contract between absent parties.

13 Tapia y Valdivia (2002) pp. 83-84; Cortez (2004) pp. 1-4; Barrientos (2008) p. 97; Vidal (2010) p. 230; De la Maza (2011) pp. 22 y 23.

14 From the beginning of the XX Century, some authors think that the expression "party autonomy" is being replaced by "private autonomy". BARCIA (2006) p. 164; VERDUGO (2008) pp. 101-102.

15 LEÓN (1991) p. 44.
} 
relationship, but above all, to the freedom to choose and give content to the contractual relationship ${ }^{16}$. But this freedom is not absolute ${ }^{17}$, and contracting requires the law to regulate, order and guarantee private autonomy, as it transcends the intimate sphere of the person, as well as the correct development of society ${ }^{18}$.

Nowadays, the importance of the principle we are discussing is remarkable, as electronic commerce is one of the areas where this aspect is clearly evident. On this basis, derivative instruments of self-regulation are possible, but their content has to be more protective than the minimum legal framework established by the legislator, regarding the potential consumers and users. If this principle were not recognized, it could be argued that the law of obligations and contracts would be severed. Within this part of the law, electronic commerce would be subject only to the decisions that the legislator deemed appropriate in each period. In other words, without this principle in place, the protagonists would also be those affected by e-commerce, and could never regulate the area in which e-commerce operations are carried out. Contractual freedom, despite representing a past achievement, continues to deploy full and absolute efficiency in electronic commerce.

While the principle of party autonomy is not stated in the Chilean Civil Code, its importance is undeniable. Unsurprisingly, as it is well known, most contracting principles are derived from it. Thus, those regarding consent, contractual freedom, the binding and the relative effect of contracts could be called subprinciples of party autonomy, while good faith would be the only one emerging as an independent factor. We will refer to this latter below.

The conceptualization of the rules contained in the documents of fair practices in e-commerce, as a manifestation of self-regulation, or in other words, as autonomous rules issued from the principle of autonomy, is based among other provisions ${ }^{19}$ on arts. 1437, 1445, 1461 in fine, and 1545 of the Chilean Civil Code (however, the latter with some dissenting opinions in a sector of the doctrine ${ }^{20}$ ) that recognize the regulatory power of party autonomy within the scope of contracts. This concept, as revealed by an important sector of the doctrine $e^{21}$, stands in a dynamic instrument of the economy and also is the strongest expression of autonomy in the strictly legal sphere.

Applying general considerations applicable to our field of study, it may be noted that the parties that interact in this scenario have complete freedom to make contractual legal relationships that could be included within the category of electronic commerce. Indeed, if consumers and/or users are interested in hiring a particular good and/or service they may do so with a company committed to a particular system of self-regulation or

\footnotetext{
16 López (1998) p. 233; Vial (2003) pp. 57-58; Rodríguez (2008) pp. 107-187; Domínguez (2012) p. 56.

17 EsCOBAR (1991) p. 49.

18 The principle of party autonomy represents the French Revolution doctrine to contracts. If rights are faculties recognized by Law, and freedom is the base of human activity, it must be accepted that the individual behaves the way he wants, provided that he follows the costumes of the country. Thus, AlesSANDrI (2004) p. 11.

19 Among others, Somarriva (1934) p. 39; Alessandri (1941) p. 5; Albeliuk (2001) p. 117; Alessandri et al. (2002) p. 47.

20 Pizarro (2004) pp. 235-236.

21 Barros (2009) p. 297.
} 
not. In the first of the cases listed, the employer, prior to the beginning of the contractual relationship, where appropriate, will have to formalize with the consumer and/or user the agreement on accession to the specific instrument of self-regulation. The adoption of the latter means that the company has to comply with certain duties of information, especially important in the pre-contractual area.

\section{The SUPply of TECHNiCAL INFORMATION FOR THE SAFEgUARDing OF THE CONSUMER: LAW No. 19.496}

The admission of pre-contractual duties of information as a category is due to a late development that is linked to social changes and the object of trade. In Roman law, it was considered that each of the parties had the duty to be informed and therefore acquire the necessary skills when entering into a contract. In fact, according to the concept caveat emptor or emptor debet esse curiosus, each of the parties must satisfy their interests in the business. This situation lasted throughout classic and modern law, particularly when the concept of pre-contractual liability started to be developed.

The pre-contractual obligations to contain certain information represent a suggestive manifestation of providing information as a good instrument to protect the weakest party in a particular contractual relationship characterized by the occurrence of certain information asymmetries ${ }^{22}$. In fact, the pre-contractual area is precisely one that is affect by instruments of self-regulation. With the expression "pre-contractual information duties" we refer to those cases in which, on a preferential basis, the aim is to defend the freedom of contract. For both scenarios, we can distinguish first, the general rule of art. 3 b) of Law 19496 on the protection of consumer rights (hereinafter LPC), and second, the specific cases according to the arts. 12) and 32 of LPC linked to electronic commerce ${ }^{23}$. We will refer to this below ${ }^{24}$.

\subsection{The general rule of art. 3 b) of Law 19496}

While in the general rules of contract law, the duty to provide information during the course of the contractual relationship is exceptional (each party must provide their own information), the same however cannot be said for consumers. Indeed, when it comes to consumer relations, a general duty of the provider to give certain information to the weaker contracting party (consumer and/or user) in the phase prior to the formation of consent prevails. In the latter case, it can be seen that we have a general rule, since it is not limited to certain types of contract, so its scope consequently extends to all consumer relationships ${ }^{25}$.

22 De la Maza (2011) pp. 115-135, talks about certain rights of information that allows the judge consider the specific variables of the case and weight the parties interests in order to determine if the information duty existed.

23 Some rules of LPC are in relation with e-commerce. For example: art. 3 bis, b), on the withdrawal right; and art. $28 \mathrm{~B}$, on the Communications and advertising rights.

24 In this issue we recommend De LA MaZA (2011) pp. 21-52.

25 We are in front of the consumer right. For SANDOVAL (2004) p. 5 it is the set of rules that regulates the relations between producers and consumers. 
Art. 3b) of the LPC states that the "basic rights and duties of the consumer [are]: the right to obtain accurate and timely information about goods and services offered, their price, contract conditions and other relevant characteristics, and the duty to be informed about them responsibly". As can be inferred from the wording of the provision noted, the information must be twofold: accurate and timely. It is important to highlight that the purpose of the information is that the will given in the contract is free and spontaneous, that is, it is formed in a conscious, rational and free way. On further analysis of each of the characters targeted, one can say that the truth can be deemed as a kind of redundant requirement. In fact, it is presumed. A sensu contrario, in this area there is an obvious ban of falsehood. Also, the information must be understandable for the consumer, which must be interpreted in the sense that its content will be accessible without an extraordinary intellectual effort or the need for third parties for clarification. Regarding the timeliness of information, as determined by an authorized sector of the doctrine ${ }^{26}$, it must be linked to the notion of art. 1.3 of LPC on "basic commercial information". In this way, in recognition of Art. 32 of this regulation, it can be inferred that such information should be made and provided in Spanish ${ }^{27}$ in legible and understandable terms.

On superficial analysis, the points which must be met by the supplied information according to the mentioned art. 3b), must focus on its content. In fact, according to this provision, the information should be about "goods and services offered, price, contract conditions $^{28}$ and other relevant characteristics". As one can appreciate, the wording is sufficiently broad. So, given that the information the average consumer needs to form their will, it seems reasonable to suggest that this will depends on the circumstances of each individual case.

Furthermore, it is essential to consider the diverse consequences of failure to observe the pre-contractual information duties. Indeed, the imposition of economic sanctions under art. 24 of the LPC is common. Furthermore, according to art. 3 e) of the same statute, there exists the possibility to exercise adequate and timely redress and compensation for material and moral damages, in the event that the obligations of the provider are breached.

\subsection{The specific assumptions: the arts. 12) and 32 of Law 19496}

In the area of e-commerce we must consider two provisions of the LPC that relate to the subject in question. First, with respect to art. $12 \mathrm{a})^{29}$, we can say that consumer acceptance as an element of consent is certainly covered ${ }^{30}$. Indeed, according to the wording of the provision, the weak contracting party must have clear, understandable and unambiguous access to general conditions relating to the goods and/or services offered ${ }^{31}$

26 De la MaZa (2011) pp. 44 y 45.

27 Given the internationalization of the Internet, it would have been better to speak about the language used in the contract proposal.

28 For the meaning of terms and conditions, De la Maza (2009) pp. 84, 85, 88 y 89.

29 For the browse contracts, De la MAZA and Cruz (2003) p. 117.

30 Baraona (2014) p. 391.

31 The mere visit of the Website offering certain products does not imply any obligation for the consumer. 
and also hold the ability to store or print them (duty related to the requirement of written form). The acceptance of the latter must be ostensive. Also, the provider ${ }^{32}$ must send a confirmation, electronically or by other means of communication, to ensure the timely knowledge of the consumer, which will contain a legible, clear and complete copy of the contract.

In addition, in the second paragraph of art. 32 of the LPC, the legislator refers to the duty of the provider to inform the consumer in a clear and easily accessible manner of the stages or phases necessary to hold the electronic contract, and where appropriate, if the document formalizing the contract will be filed, and whether it will be accessible to the consumer. To complement this, the need for the provider to set a means of contact (postal or e-mail address), and if necessary, to indicate the procedure to correct errors that may arise.

In any case, guardianship granted by the Chilean legislator in this matter seems precarious. Thus, although it refers to the steps to be taken for the e-contract to be finalized, notable aspects are omitted, such as the fact of claiming the identity of the supplier and its geographical location. These aspects are seemingly essential in the field of electronic commerce. Now, it could be possible that self-regulatory instruments establish the need for companies adhered to them to incorporate these and other issues for the potential consumer and/or user. In fact, given the paucity of the terms of the Chilean legislator in this matter, it would be desirable for good practices instruments to be developed in this regard, establishing that providers indicate aspects that ensure greater provision of information to the consumer. This information should include: information about the full identity of the provider (establishments and address); whether there are delivery costs any involved; types of payment, delivery or execution; validity of the offer ${ }^{33}$ or fixed price; and the higher cost involved by using distance communication techniques in contrast to the basic rate.

\subsection{Good faith as the basis of pre-contractual duty of disclosure}

The general principle of good faith ${ }^{34}$ that as of today the doctrine qualifies as objective $^{35}$, as opposed to the good faith belief that is understood to be subjective in essence, is set in the Chilean legal system in one of the basic precepts of Book IV of the Chilean Civil Code regarding the treatment of obligations and contracts ${ }^{36}$. We refer essentially to art. 1546 of such regulation ${ }^{37}$.

\footnotetext{
32 This aspect could be met with a simple link in the website of the company that sends the user to the general conditions, and a space dedicated to the agreement that he can click on with the mouse.

33 The offer must be firm, as Domínguez (1980) states, in the sense that it must express a firm will to sign a contract in case of being accepted.

34 GUZMÁn (2002) pp. 11-23.

35 Eyzaguirre and Rodríguez (2013) pp. 137-216.

36 Corral (2006) p. 187.

37 Some authors like Carvajal (2009) pp. 31-45, have rejected the possibility to base it under the article 706 of the Chilean Civil Code.
} 
Good faith is a general principle of $\mathrm{law}^{38}$, and as such, should extend its scope to include contract negotiations (being present throughout the contractual iter). As a general principle, it represents a vague concept, but is extraordinarily rich in practical applications that the Chilean legislator uses to inspire numerous civil institutions. In the background, there is a kind of model behavior which is considered suitable or appropriate for the society of the moment. Such conduct is legally enforceable, and rewards those that act in accordance with it, yet penalizes those that act against it (bad faith).

The role model that good faith implies, presents firstly a component of loyalty ${ }^{39}$ towards achieving the intended purpose, and second, to safeguard confidence in the behavior of each part, as it is considered to have faith in the correctness or in the goodness of the reciprocal behavior of the parties.

In contractual relations, the principle of good faith is identified with trust, honesty, and in some cases, ethics ${ }^{40}$. The specific application of the principle of good faith within the contracting field will mainly take place in those acts involving mutual trust.

Good faith is a duty of information from one party over the other. In this sense, each has a duty to inform the circumstances that are unknown to the other and that may be important to the delivery of the consent (those that if known would have led the other party not to sign the contract, or to sign it under different conditions).

It should also be considered that good faith is a desirable and necessary general clause in legal systems. In fact, it can be interpreted as a valve that regulates the pressure of ethical and social requirements, thereby avoiding a law which is impervious to social changes ${ }^{41}$. Although derivative instruments of self-regulation are updated with some regularity because, among other factors, the formal procedures are not as tedious and lengthy as the legal norms, the presence of the principle of good faith plays a similar role.

The question of imposing pre-contractual information duties is closely related to the interests that they aim to protect. These interests include the protection of contractual freedom, understood as the freedom of choice. This means that the contract represents the preferences of the parties, and in order to fulfill this objective, free and thoughtful consent is required. In this regard, it should be considered that the pre-contractual information duties may, to some extent, be seen as devices favoring such consent. Also, a second protected interest worthy of mention is market guardianship. In this sense, there is a list of rules, such as those of publicity, which are not directly aimed at the formation of consent, but to the supply of goods and/or services in the market to operate competitively. To this end, the intention is that potential consumers and/or users have sufficient information to discriminate between different suppliers in the market. Another significant interest to safeguard would be linked to what could be considered as a kind of contractual loyalty that the parties would be asked for during the contract. Under such a premise, during the

\footnotetext{
38 Fueyo (1990) pp. 153-162; SAAVEdra (1996) pp. 357-373.

39 A doctrine sector distinguishes a higher degree of intensity of the good faith principle in special trust situations. Along these lines, MeKki and Kloeper (2008) p. 346.

40 Hesselink (1999) p. 33; Jaluzot (2001) pp. 38-39; Segura (2010) pp. $499-510$.

41 Ruz (2011) p. 32.
} 
contract, each party may trust that the other will act with loyalty and honesty ${ }^{42}$. The fourth interest which should be mentioned concerns the diligent conduct of the people involved in contract negotiations. Thus, individuals should be responsible for their statements, even if they do not want to be.

Despite the fact that the contractual iter (a clear presence of the principle of good faith) should be present at all times, we must not forget that the consumer, especially in electronic commerce, should be likewise self-informed. Article 3 of LPC, in fine, alludes to this issue of the basic rights and duties of consumers and states their duty to inform themselves responsibly. It is not a duty but a burden ${ }^{43}$. Note that the offence does not carry responsibility. Actually, it is the supplier that holds a duty to inform. If this responsibility is breached, the provider will have to compensate any damages caused to the consumer and/or user. Yet, as we have said, users must be reasonably informed ${ }^{44}$, because otherwise they may not achieve the desired result (namely, compensation for damages due to lack of information). We understand that established self-regulatory systems in electronic trade contribute to this in two respects. First, in terms of its articles, as we shall see, the documents of good practices establish an improvement in the minimum rights established by the legislator to protect the consumer and/or user. These benefits are, among other things, visible in the information to be provided by the supplier to potential customers and/or the users who wish to form a contract with them ${ }^{45}$. Second, self-regulatory systems positively affect this duty of self-report that, as stated, is predicable to the consumer. In fact, among other objectives, such tools pursue the education of the weakest contracting party in electronic commerce.

\section{SELF-REGULATION OF COMMERCE}

E-commerce requires a regulatory framework that takes into account both its global nature and defining characteristics. Evidently, online electronic trading has its own characteristics because of the telematics means used as a channel for providing consent. In order to take them into consideration, developing a promising complement to the legislation, the agents interacting within this area have approved an appealing set of derivative instruments of self-regulation. Next, we will analyze independently various aspects of the latter.

\section{CONCEPT AND CHARACTERS}

Self-regulation is a phenomenon that is not at all recent. Any organization or individual is self-regulating in one way or another. This fact is legally relevant when that self-regulation is beyond the domestic or private framework, projecting its effects on a

\footnotetext{
42 Pinochet (2005) p. 31.

43 PeñAilillo (2003) p. 80 states that a certain conduct is necessary to achieve a specific result.

44 Some authors (FERnÁndez (1998) p. 115; Perret (1999) p. 23) highlight the responsible attitude expected from the consumers.

45 In line with the opinion of KRAUSZ (2011) p. 247, who states that the market competitiveness is increasing and the consumer information is higher every day.
} 
considerably broader range (in certain cases, it will be supranational), reaching, in turn, the public organisms. It is precisely the public effects of self-regulation that explain the growing interest in favor of what might be called public control of private self-regulation (also called regulation of self-regulation).

It is obvious that self-regulation is developed between the society and the state, between the private and the public. Simultaneously, it focuses on the self-discipline that arises in private orbit, but which obtains public relevance. As self-regulation is a more informal practice than legislation and has no coercive capacity (understood in the sense of virtuality and close outreach to the State), its efficacy can be very weak if not given a favorable cultural environment and the organization of all participants.

It should be also noted that self-regulation cannot be seen as an excuse to exempt the legislative power of its obligations, but as a complement to a legislation that, inevitably, can only have a very broad and ambiguous character.

It is important to recognize that the possibility of achieving the general interests is attributed to private organizations and persons. Also, there need to consider certain private standard setting instruments developed by these entities as important tools that can be used by the administration for the fulfillment of its purposes.

From this perspective, self-regulation may offer solutions to certain issues raised beyond established legal norms. The latter, with its general and abstract statements, can hardly pronounce about what, in most cases, are very particular situations of a particular group or type of subject that has its own specific problems.

In this sense, it can be said that self-regulation is linked to the articulation of new regulatory strategies promoted by the authorities. Under the latter, it attempts to improve the participation and responsibility of individuals in compliance with certain public objectives, ensuring efficiency, but also the consistency of the legislation. Actually, it is about improving the effectiveness of state regulation.

Self-regulation in electronic commerce is the management carried out by subjects who are actively involved in the development, creation, implementation and dissemination of electronic commerce and interactive advertising, to voluntarily impose upon themselves a set of rules, or good practices, in this field. As will be appreciated, "self-regulation" is a word that implies, on the one hand, a policy development and on the other, an internal volitional capacity of the subjects participating in the system to meet the different rules (good practice documents, such as a code of conduct) drafted by themselves. Selfregulation also includes the capacity to control the execution of documents derived from one party to another, and also a sanctioning capacity.

Self-regulation of electronic commerce, in particular when it is cross-border, is a manifestation of the growing development of transnational or extra-state rules (different from state legislation and international standards, basically integrated in international conventions) relevant not only for the management of commercial relations, but also for the protection of consumers in an environment of expanding international consumer contract.

The advantages that the adoption of the various techniques of self-regulation can provide are different. Derivatives of self-regulation allow for increasingly faster adaptation 
to technological, economic and sociological changes than conventional management channels. This fact is significant in a sector as dynamic and changing as the Internet. We are not facing a new problem, as traditionally law has solved problems regarding the application of technology, albeit with some delay, as they have produced new challenges for the legislative body of the doctrine. Such drawbacks inherent to the process of developing standards, could be avoided or at least diminished through the codes of conduct regulating e-commerce, as such standards of conventional origin resulting from self-regulation, have a significantly shorter and less formal elaboration period than legal standards, while their ability to adapt to technological changes is markedly higher. Other prerogatives of self-regulation that should be highlighted are: flexibility (due to a constant process of technological change, among other factors); specialization; encouraging the development of standards that ensure high levels of correction; transparency; preventing breaches in the regulated area, especially if they have prior evaluation mechanisms, for example, in our case, of interactive advertising before release or dissemination (copy advice); low cost, in different areas, such as proceedings for infringements; the fact of covering any legal gaps; and easy access.

Also, the vocation of integration and coordination at the supranational level, which usually devises these techniques, represents the perfect way to overcome the problems and the limits that globality and lack of territoriality on the Internet can cause for the courts.

\section{PREREQUisites}

In this section, we will refer in passing to the specific elements that must be included in a self-regulatory system for it to be complete and effective. The lack of any of the compulsory requirements or their malfunction will determine the system to be inefficient and incomplete. In this sense, it would not meet the necessary requirements to consider it as a real e-commerce computer system. We believe that certain elements must be present in order to consider a system to be a really effective instrument of self-regulation in electronic commerce (a selfregulatory system) which will naturally comply with government regulations. Some of them will have a constitutive nature, while others, by contrast, are complementary or accessories. First, we will outline each one based on their type, and then we will move on to their analysis.

There are two constitutive requirements. On the one hand, the code of conduct or regulatory document of recruitment and interactive advertising, which can be consulted electronically and must be written at least in the language of the place of establishment of companies adhered thereto. And, secondly, the inspection body or dispute resolution mechanism court to resolve disputes wherever appropriate between member firms and consumers or users that, in one way or another, contract goods and/or services, including promotion and interactive advertising actions. In other words, the extra-judicial dispute resolution mechanism will rule on the existence or non-existence of a possible breach of the code of conduct (in which it is integrated) imposing the corresponding sanction under that code where appropriate.

Regarding ancillary requirements, the following two may be mentioned. First, the agreement or prior disposition of all agents that directly or indirectly interact in the sector in question. Second, the quality stamp or trust seal representing that the company displaying 
it has successfully completed audits or controls established by the entity responsible for the system, meaning that it is worthy of the trust guarantees that joining the system implies. Although, we insist that these requirements are not mandatory, joining the system of selfregulation seems very important for two reasons. On the one hand, in the case of the code of conduct, it relies on the approval of all potentially susceptible agents to be affected by it, achieving a consensus text. It will tend to be seen as self-imposed, as the degree of compliance will be higher than otherwise, since its elaboration meets the interests of all. Furthermore, the trust seal is the graphic sign that defines the business community that complies with the good practices in the articles of the ethical code. It would be enough that the potential consumer and/or user saw and, consequently, knew its meaning, so that the presence of the logo could fulfil its potential of exactly what it was designed to do: to prove the adherence to a particular system of self-regulation and, thus, the list of improvements that are available to potential consumers and/or users. Regarding the latter point, it should be noted that not all codes recognize the same degree of legal improvements for the consumer and/or user.

\subsection{Mandatory}

Now, we will individually address the two constituent requirements set out above. On the one hand, the code of conduct, and secondly, the inspection body.

First, one of the core elements of self-regulation systems in e-commerce are the codes of conduct. Apart from being an important development, since they move the task of regulating a particular subject to the private sector, they represent a breakthrough, as the public sector is aware of the numerous advantages that self-regulation offers electronic trading.

Codes of conduct in e-commerce, can be defined as voluntary documents which include a set of principles, rules, or, in short, good practices, certifiable by an independent third party. They rule matters relating to pre-contractual, contractual and post-contractual procedure, concerning electronic trading, notwithstanding other related issues. Its purpose is the establishment and strengthening of consumer and potential user confidence.

The adoption of a code of conduct with subsequent accession by a certain company that offers its services through electronic contract means, if its true meaning and scope were known, would represent an element highly valued by the public (consumers and users) at which such instruments are targeted. The real problem is the ignorance that exists about them. To date, two main codes of conduct on this issue prevail in Chile. On the one hand, the code of fair practices for e-commerce of the Chamber of Commerce of Santiago ${ }^{46}$, adopted in June $2014^{47}$, and on the other hand, the code of conduct on interactive advertising of IAB Chile, approved in September 2012.

46 The Chamber of Commerce of Santiago established the "Alianza por las Buenas Prácticas en Internet", in which private and public parties participate. For example, apart from the Chamber of Commerce of Santiago, the Banks and Financing Institutions Association, the Chilean ICT Association, the Internet suppliers Association, etc.

47 There is a previous document, from 2005, by the Chamber of Commerce of Santiago, in cooperation with BBBOnline, Global Trust Alliance and Banco Interamericano de Desarrollo. De LA MAZA (2012) pp. 305-308. 
Codes of conduct are, for the acceding employer ${ }^{48}$, a firm commitment of compliance with its rules, whose content guarantees, in addition to compliance with the prevailing law in all e-commerce trading and other things, such as advertising, the protection of minors and human dignity, protection of personal data ${ }^{49}$, intellectual property, transfer of goods or services not requested, etc. This is an additional plus that sometimes improves the minimum protection recognized at the legal level for consumers and users, and that must be respected by firms that adhere to these instruments. In the case of Chile, the code of conduct of the Chamber of Commerce of Santiago regulates various sections relating to electronic commerce ${ }^{50}$, while its namesake of IAB Chile focuses only on online advertising.

Obviously, this practice builds confidence for consumers and users, because when they understand their meaning, they have the opportunity to know that an entrepreneur is the signatory by showing the stamp or trust seal on the website of the adhered company which it represents, a specific code of fair practices for e-commerce. Although they undoubtedly generate trust, it will not be the same in all cases. Indeed, its extent will depend on several factors, among others, the prestige or importance of the institution or author responsible for the code of conduct or the type of member companies. In the case of Chile, the tools of fair practices, to which we have been referring, have been sponsored by representative entities in the sector (Chamber of Commerce of Santiago ${ }^{51}$ and IAB Chile $\left.{ }^{52}\right)$. Notably, there was a code of good practices on electronic commerce in the past, which although did not last a long time, it was also launched by a Chamber of Commerce, namely, Confiare ${ }^{53}$.

It could be assumed that the codes of conduct did not provide significant improvements of legislation passed by the legislator, representing, thus, a simple systematic collection of rules governing the electronic trading or interactive advertising, without adding any minimal additional defending advantage (which the legislator recognized) in favor of the weakest contracting party. The last assessment made is not trivial in any way. Indeed, if they tried to become a publicity gimmick, creating legitimate expectations among consumers and/or users, making believe that they attach an additional plus of what makes the prevailing legislation, and if it were not true, they could be considered unfair

\footnotetext{
48 In the case of Chile, as it has been mentioned, there are two codes of conduct in relation with e-commerce. The first one, the Chamber of Commerce of Santiago, was compulsory for the members of the E-commerce Committee but voluntary for the external members of the Chamber. The second one, called sistema de confianza IAB Chile, was compulsory for all members of IAB Chile.

49 The consumer, according to Law 19628, can decline the use of his personal information form commercial or research purposes.

50 The document has seven main areas such as advertising, e-contracts, etc.

51 The Chamber of Commerce of Santiago is a non-profit organization founded on 1919. It has more than 2000 member companies, representing all economic sectors.

52 IAB Chile is part of the World net Interactive Advertising Bureau-IAB-, a well-known entity in the on line advertising sector.

53 This initiative was an idea of the Chilean National Chamber of Commerce, Services and Tourism. It represents a leader organization of Chilean commerce since more than 140 years ago.
} 
by misleading (ex arts. 3 and 4 b) of Law No. 20169 of unfair competition and Art. 28 of LPC).

In addition to the codes of conduct that currently prevail in Chile, in the field of electronic commerce, we must highlight the list of good practices in the same subject that are identified by SERNAC. In other words, this body identifies a number of sections that constitute a kind of good practices in the area of information, which must be present in the websites of suppliers. In this sense, the following areas can be listed: corporate identity; information relating to the transaction; privacy policies; and finally website security. SERNAC has monitored the presence of such practices in several studies.

Secondly, we should refer to the control body. The resolutions of such bodies for conflict resolution established in each system are based on self-regulation codes of conduct signed by entrepreneurs adhered to the system. Considering that one cannot speak of an ethical behavior outside the law, the first ethical mandate that inevitably must follow selfregulatory systems is the need to adapt to the law the operations conducted in the area of electronic commerce, resolving the differences that may arise in practice.

In order to be considered a real control body, it must meet the characteristics of independence and impartiality. The independence of the body responsible for making the decision will be ensured, so that the impartiality of its actions is assured. When the decision is taken individually, this independence will be confirmed by the occurrence of the following measures: the person appointed possesses the abilities, experience and competence, particularly in law, required to function; the maturity of the mandate of the person appointed should be sufficient to ensure the independence of his/her action, and that person may not be dismissed without just cause; and when the person concerned is appointed or remunerated by a professional association or a company, he/she must have worked for the association or for one of its members, or the company in question during the three years prior to starting this function. In the event that the decision is taken by a collegiate body, the independence of the body responsible for it can be ensured by giving equal representation to consumers and professionals or by complying with the aforementioned criteria.

In the case of self-regulatory systems in force in Chile, in the field of electronic commerce (both the system designed by the Santiago Chamber of Commerce and that by IAB Chile), there are no sufficient evidence to guarantee the independence and impartiality of the inspection body. In fact, the regulation in this respect, by both regulatory documents, is really sparse. It seems that we are facing documents that carry out a task of mediation $^{54}$.

Evidently, consumers, require fast, efficient, cheap (and even free, considering the meagre effective economic value of the goods or service hired) mechanisms that enable the settlement of disputes arising in e-commerce with companies that undertake any contractual relationship ${ }^{55}$.

\footnotetext{
54 The E-Commerce Committee was created for the Chamber of Commerce of Santiago code of conduct, while the Ethics Committee was created for IAB Chile.

55 KaTSH (2004) pp. 1101-1121.
} 
Another feature present in the self-regulatory systems is that handling complaints is free for consumers and/or users. So, they obviously will not incur any costs for the resolution of the dispute, under the procedures established by the organs of self-discipline, unlike what would happen if they had to resort to judicial mechanisms, as they not only entail high costs for litigants, but the majority of cases involve a long wait until the resolution of the conflict by ordinary courts of judges. We demonstrate the composition of the courts to make a difference with respect to the subjects that will solve the issue in the self-regulation procedure of dispute resolution because, as a general rule, they are experts in the field, giving thus a solution adjusted to the controversy.

\subsection{Accessories}

Returning to ideas that we have mentioned, it is worth recalling the two accessory requirements of self-regulatory systems. First, the agreement of all the actors involved in the interaction. Secondly, the graphic stamp that certifies the membership or the commitment to the fair practices document.

As regards the first of the requirements, it can be said that the solvency of selfregulation in electronic commerce and in many others, depends to a large extent on the direct or indirect participation of all parties involved (understanding that representation is included in participation). With the collaboration of all social agents, the manifestations of self-regulation will not only be more successful and rational, but also will become the basis for preventing and, to some extent, neutralizing possible conflicts between participants.

Regarding the type of subjects that should be part of the group preparing the reference document for the system of self-regulation, the codes of conduct, there must be representatives of all groups that interact in e-commerce. It enables a consensus text to be achieved that, in a sense, ensures the independence and impartiality of the code of conduct which is drafted. In the case of Chile, however, there are no elements that allow us to consider that the content of the provisions of the articles of the codes of conduct prepared by the Chamber of Commerce of Santiago and IAB Chile, were profiled together with all the groups likely to be affected. It seems rather that these texts were made by specific committees integrated into each of these institutions, and hence without the participation of other collectives.

Secondly, the presence of a label of trust in a website, representative of the adherence to a particular system of self-regulation, means that the entrepreneur who holds it agrees to comply with the articles present in the code of conduct to which the trust seal belong in all its activities. In other words, the commitment of suppliers with any of the systems discussed, is a recognition of the quality of the companies that have signed it. They seek a better market positioning with the display of the trust seals, which translates into greater competition in trade, benefiting, in a sense, the prestige that the seal means.

The display of that seal, apart from instilling confidence in the target public, will be doubly effective. On the one hand, it will advertise, directly, without any consideration, the system of self-discipline in electronic commerce, to which the sign belongs, as pressing on the seal in question, they will gain full access electronically, so that they can discover, on a global basis, the terms of service. On the other hand, indirectly, by presenting the seal, 
member companies contribute to giving greater prestige and social recognition to the tool, which naturally gives a higher quality, goodwill or good fame to the service provided by the system of self-regulation. If the entrepreneur does not act according to the list of good practices included in the code of conduct, besides being able to be a case of misleading advertising, the control body may impose a sanction that, according to the impact, could be a mere warning, suspension of rights, of even expulsion from the system itself, which also could be actively publicized. The sanction must be fulfilled by the adhering entrepreneur author of the wrongful act, regardless of whether, after its commission, he leaves the system of self-regulation. Both the code of the Santiago Chamber of Commerce and the IAB Chile contemplate the possibility to lose the trust seal. However, the first one refers in more detail to the causes for which the stamp may be lost ${ }^{56}$. The second (IAB Chile) refers to the license agreement being formalized with the appropriate supplier. We believe that for the purposes of greater legal certainty, it would have been more appropriate to follow the option of the code of conduct of the Santiago Chamber of Commerce.

\section{LEgAL NATURE}

Next, we will highlight the legal nature that, in our opinion, the codes of conduct in e-commerce deserve. We should note that, perhaps, in part, because of the youth of the figure (and not because of its potential, which seems to be very high) the doctrine that has ruled on its legal nature is extremely limited. In this regard, we must make a double distinction.

\subsection{The unilateral codes of conduct on the subject (which are not integrated into any system of self-regulation)}

In some cases, we might understand that we are faced with a unilateral declaration of intent. The latter, for which various denominations ${ }^{57}$ have been made, can be defined ${ }^{58}$ as the source by which the expression of will of a subject generates an obligation for him/ herself, without needing the will of a correlative creditor. Although the Code of Bello does not expressly and formally state ${ }^{59}$ the unilateral declaration of intent as a source of obligations, we understand that it must be admitted according to an authoritative doctrinal power ${ }^{60}$. Since a subject emits a will containing significance and intending to be enforced, it encourages or promotes interest, activity and confidence in others. So, it must not be tolerated that later, a party (in our case the company or provider) can be separated, at its discretion, from the consumers and/or users that form a contract with that supplier.

As practice shows in e-commerce ${ }^{61}$, such an approach could be considered in the case that the code of conduct was imposed or approved by the entrepreneur as a statement

56 For this issue, art. 34 of the good practises code of the Chamber of Commerce of Santiago.

57 Among others, unilateral promise or unilateral will.

58 PeÑAilillo (1999) p. 7.

59 In this sense, arts. 578, 1437 y 2284 of the Chilean Civil Code.

60 Peñailillo (1999) pp. 19 y 22.

${ }^{61}$ It does not mean that it could not happen. In fact, an e-commerce supplier could approve a code for itself. 
of fair practices formulated by himself but also to be fulfilled by him, without a promoter or an organ responsible of its application.

However, it does not seem permissible in the case of the so-called codes of conduct regulating e-commerce (such as those approved by the Santiago Chamber of Commerce and $\mathrm{IAB}$ Chile), as it must not be forgotten that they are written by the promoter of the self-regulatory system, formalizing later their accession to the provider (to be applied to the contracts, the latter signs with consumers and/or users to initiate contractual relations). Similarly, for the duration of the code of conduct, prior agreement should be signed between the promoter and the supplier. When the unilateral promise had been accepted by the recipient, i.e. the receiver has accepted the offer, it would not be unilateral will, but the contest of wills which would determine the rise of the obligation. In case of breach of those, the possible violation would be subject to sanctions (to restore the situation to the starting point at which the breach was not met) by the inspection body established by the self-regulatory system. In any case, this position (the unilateral declaration of intent) may itself be admissible in codes of conduct drafted per se by the company that undertakes, unilaterally, the obligation to respect them, although they may also be produced by a third party. Normally, these documents include, in their articles, ethical rules applicable to the daily operations of the company in many aspects.

\subsection{The codes of conduct that are integrated into a system of self-regulation}

In the matter under review, we can make a relevant clause, which is that there are two distinguishable contractual legal relations, but which are interrelated. On the one hand, the contract between the promoter of self-discipline systems (which, in the cases provided will be the Chamber of Commerce of Santiago and IAB Chile) and suppliers, whereby the adhesion to self-regulatory instrument is formalized and, moreover, the contract between the provider committed to the document of good practices and the consumer and/or user is made. On the other hand, the contract between the provider signing the fair practices document and the consumer or user, by which the latter hires a good and/or service, resulting in the legal relationship that, among other regulations, shall be governed by the articles of good practices document initially signed by the supplier. Although such contracts may differ, they are certainly interrelated, having an important link between them, in which good faith will occupy a prominent place. We have referred to the latter above.

Concerning the legal nature of the code of conduct to which the provider adheres, about the first legal relationship, we can say that it is atypical. To our knowledge, advancing the conclusion that we will reach in this section, it can be demonstrated that it is a standard contract for the benefit of third parties. We will now justify our argument.

The standard contract is housed in a voluntary agreement under which the parties predispose the terms of future contracts. By concluding this type of contract, the contracting parties adopt a model aimed to be reproduced in many subsequent cases, without substantial alterations. Somehow, each of them will be equivalent to a pre-written contract. To date, its usefulness is beyond doubt. But the concept we analyze is not without its problems. Indeed, in the case of unilateral contracts, companies can impose clauses limiting rights to consumers 
and/or users starting contractual relations with them. The standard contract may be one of two types.

It is unilateral when the parties who conclude the contract aimed at establishing the clauses (or, if any, commercial traffic general conditions) are economic groups or companies with converging interests ${ }^{62}$. In this case, companies do not trade in any way with future clients. Thus, there remains a strong link between standard contract and contract by adhesion. The latter is offered as an invitation to accept a standard contract. Usually this will be the type in which the promoter of the self-regulation system (Santiago Chamber of Commerce and IAB Chile) develops codes of good practice, without the participation in its development of other agents, such as representatives of consumers and/or users.

When the parties involved in the completion of the standard contract have divergent interests, the standard contract is bilateral. This is the case we find precisely when representatives of the recipients of the documents of good practices participate in preparing its clauses ${ }^{63}$.

On the other hand, in our view, the concept discussed is also linked to the contract in favor of a third party or with provisions in favor of a third party, recognized in art. 1449 of the Chilean Civil Code, which can be defined as one contractual arrangement whereby a part (called promitente) agrees with another (estipulante) to make a provision in favor of a third party who has not been involved, directly or indirectly, in the celebration of the business and that there is not, therefore, obliged nor bound by the latter. The characteristic of this contract is the attribution of a right or stipulation directly to the third party (for the benefit of a third party).

In the contract in favor of a third party, there are three subjects: the two contracting parties signing the business and the third who benefits from it. Their names are promisee, promisor and beneficiary. The promisee is the one fulfilling delivery promise. The promisor is the contracting party obliged to do something for the third party. Finally, the beneficiary (or the third party) is the one to whom the service is provided. We can analyze the characteristics of the contract in the field of e-commerce self-discipline. A promise is made by the promisee (entity promoter of the code of conduct) and is accepted by the promisor (entrepreneur). This promise is directed to deploy all its positive effects in favor of a third party (potential consumer and/or user) that, precisely, based on the above mentioned contract, was previously held by the promisee and the promisor.

It should also be noted that the provision in favor of a third party is not a credit right, but the recognition of a frame that gives special protection to the rights of the consumer and/or user (more beneficial than the minimum one established by the legislature) in the electronic contract signed with the promisor, who will act as supplier.

\section{Failure To Comply With The Self-Established Good Practices}

Once the e-commerce consumption has taken place, taking into consideration arts. 12 of the LPC and 1545 of the Chilean Civil Code, we can say that it is binding for

\footnotetext{
62 Maldonado (1998) p. 168.

63 For example, Confianza Online y Anetcom.
} 
the parties involved, which naturally cannot change it unilaterally. Beyond the national level, the Organization for Economic Cooperation and Development (OECD) has acknowledged the validity of the earlier demonstration, because companies must comply with any statement made about its policies and practices relating to their transactions with consumers $^{64}$. Within this, all that entails adherence to an instrument of good practice must be included.

Indeed, one of the most significant questions that codes of conduct raise is precisely what is its real effectiveness and, in this sense, what happens in case of default. In this regard, the answer, apart from the possible action by the courts, is in the sanctioning power of the control body of the self-regulatory system. Such an authority, of a coercive nature, is subject to the degree of commitment that the sanctioned company has.

A particularly controversial case would be determined by the possible consequences of a trust seal display (showing the adherence to a certain code of conduct on e-commerce) on the website and/or different instruments or advertising channels of the company, and the subsequent breach of the inherent obligations that it represents.

Advertising integrates the content of the contract. Everything that the company offers the potential consumer and/or user, must be satisfied in full. According to art. 1.4 of the LPC, and given the principle of advertising integration of the contract, the objective conditions contained in advertising ${ }^{65}$ until conclusion of the contract, are considered incorporated into it, in the same way as if they had been written in it. In other words, it is the entrepreneur who must comply strictly both with the agreement and with what is offered by advertising through various means (including digital means). This includes adherence to self-regulation instruments. If such a provision relates to the field of e-commerce codes of conduct, it will be consider the full applicability of the obligations assumed by the supplier. It could be the concurrence of the these (through display of respective trust logo) that precisely arouse the intention of hiring in the potential consumer and/or user who, in good faith, began contractual formalities necessary to acquire, under the conditions set out in the code of conduct, the advertised business ${ }^{66}$. Consequently, as that which is offered does not match that which is advertised (even in the purely legal sphere or contractual regime of agreement), there would be a breach of contract by the supplier, whose initial attitude would disappoint consumer and/or user expectations ${ }^{67}$.

\footnotetext{
64 The OCDE states that this is a manifestation of the equity principle in entrepreneurial, marketing and advertising practises. In this sense, the OCDE Recommendation for consumer protection in e-commerce of December 9, 1999.

65 For the difference between advertising and commercial Basic information -art. 32 of LPC-, PizARro and VAllespinos (1991) p. 43; Fernández (1998) p. 116; Fernández (2003) p. 50.

66 In the case of Chile, as IAB Chile mentions, the on-line advertising investment grew in 2013 to reach 65.3 billion pesos, which means a 22\% increase from 2012 .

67 Cancino (1993) p. 22.
} 


\section{CONCLUSIONS}

E-commerce, given its prerogatives, is one of the most characteristic pillars of the current technological revolution. As a result of the globalization of commercial operations in both the physical and digital world, there is a need for a legal regulation that disciplines the problems that arise in the context of activities related to such contracting.

Such a regulation will not only come from the government. Indeed, the various agents interacting in electronic commerce discipline, by consensus, various issues related to electronic commerce, through the adoption of instruments derived from self-regulation. This aspect is possible by virtue of the principle of autonomy.

In any case, as we have had occasion to note, a system of self-regulation must meet a number of assumptions that are likely to be classified into two main groups: mandatory and accessories. Although they have been analyzed individually, it must also be considered with regard to the codes of good practice in Chile.

These are instruments that, by virtue of their inherent advantages, are erected in an attractive complement to the legislation, which are likely to appreciably increase the confidence that a consumer and/or user displays on the web.

\section{CITED REFERENCES}

Albeliuk, Rene (2001): Las obligaciones (Santiago, Editorial Jurídica de Chile).

Alessandri Rodríguez, Arturo (1941): "El contrato dirigido", Revista de Derecho, Jurisprudencia y Ciencias Sociales, vol. XXXVIII: pp. 5-14.

Alessandri Rodríguez, Arturo; Somarriva Undurraga, Manuel; Vodanovic Haklicka, Antonio (2002): Tratado de las obligaciones (Santiago, Editorial Jurídica de Chile).

Amblard, Philippe (2004): Régulation de l'Internet, élaboration des règles de conduites par le dialogue internormatif (Bruxelles, Bruylant).

BaraOna GonZÁlez, Jorge (2014): "La regulación contenida en la ley 19.496 sobre protección de los derechos de los consumidores y las reglas del código civil y comercial sobre contratos: un marco comparativo", Revista Chilena de Derecho, vol. 41, No 2: pp. 381408.

Barrientos Camus, Francisca (2012): "Derecho del consumo", Revista Chilena de Derecho Privado, No 18: pp. 215-222.

Barrientos Zamorano, Marcelo (2008): Daños y deberes en las tratativas preliminares de un contrato (Santiago, LegalPublishing).

Barros Bourie, Enrique (2009): "El contrato y el hecho que causa daño como antecedentes de la responsabilidad”, en Pizarro Wilson, Carlos (coord.), Estudios de Derecho Civil IV, Jornadas Nacionales de Derecho Civil (Santiago, LegalPublishing) pp. 297-313.

Cancino, Mario (1993): "La relevancia contractual de las comunicaciones publicitarias. Un enfoque civilista”, Derecho y Humanidades, No 3-4: pp. 13-31.

Carrasco Blanc, Humberto (2000): Contratación Electrónica y Contratos Informáticos (Santiago, La Ley). 
Carvajal, Patricio (2009): "Artículo 706 del Código Civil chileno: crítica como pretendido núcleo textual del principio de la buena fe", en Pizarro Wilson, C. (coord.), Estudios de Derecho Civil IV, Jornadas Nacionales de Derecho Civil (Santiago, LegalPublishing) pp. 31-45.

Corral Talciani, Hernán (2006): "La aplicación jurisprudencial de la buena fe objetiva en el ordenamiento civil chileno", en De la maza Gazmuri, Iñigo (edit.), Temas de contratos (Santiago, Ediciones Universidad Diego Portales) pp. 187-226.

Cortez Matcovich, Gonzalo (2004): El nuevo procedimiento regulador en la Ley No 19.496 sobre protección de los consumidores (Santiago, LexisNexis).

De la Maza Gazmuri, Iñigo (2011): "La distribución del riesgo y la buena fe. A propósito del error, el dolo, y los deberes precontractuales de información”, Revista de Derecho de la Pontificia Universidad Católica de Valparaíso, vol. XXXVII, No 2: pp. 115-135.

De la Maza Gazmuri, Iñigo (2009): "Ofertas sujetas a reserva: A propósito de los términos y condiciones en los contratos celebrados por medios electrónicos”, Revista de Derecho, vol. XXII, No 2: pp. 75-95.

De la Maza Gazmuri, Iñigo (2012): "Plataformas electrónicas y protección de los consumidores: el caso chileno", en Consumidores (Santiago, Albeledo Perrot. Legalpublishing, Thomson Reuters) pp. 305-308.

De la Maza Gazmuri, Iñigo y Cruz Cruz, Sergio (2003): "Contratos por adhesión y plataformas electrónicas”, Alfa Redi: Revista de Derecho Informático, No 117: pp. 12-53.

De la Maza Gazmuri, Iñigo (2011): "El suministro de información como técnica de protección de los consumidores: los deberes precontractuales de información”, Revista de Derecho de la Universidad Católica del Norte, vol. XVII, No 2: pp. 21-52.

Escobar Fornos, Iván (1991): Los contratos. Parte II (Santiago, Editorial Jurídica de Chile).

Eyzaguirre Baeza, Cristóbal y Rodríguez Diez, Javier (2013): "Expansión y límites de la buena fe objetiva - a propósito del "Proyecto de Principios Latinoamericanos de Derecho de los Contratos", Revista Chilena de Derecho Privado, No 21: pp. 137-216.

Fernández Acevedo, Fernando (2004): "El documento electrónico en el derecho civil chileno. Análisis de la Ley 19.799”, Ius et Praxis, vol. X, No 2: pp. 137-167.

Fernández Fredes, Francisco (1998): "Nueva Ley del Consumidor: innovaciones y limitaciones", Revista Perspectivas en Política, Economía y Gestión, Facultad de Ingeniería y Ciencias, de la Universidad de Chile, vol. I, No 2: pp. 107-126.

Fernández Fredes, Francisco (2003): Manual de Derecho chileno de protección al consumidor (Santiago, Editorial LexisNexis).

Fueyo Laneri, Fernando (1990): Instituciones de Derecho Civil Moderno (Santiago, Editorial Jurídica de Chile).

GuZmán Brito, Alejandro (2002): "La buena fe en el Código Civil de Chile", Revista Chilena de Derecho, vol. 29, No 1: pp. 11-23.

HesseLinK, Martijn (1999): De redelijkheid en billijkheid in het Europese privaatrecht (Deventer, Kluwer).

JaLUZOT, Béatrice (2001): La bonne fide dans les contrats, Etude comparative de droit français, allemand et japonais (París, Dalloz). 
KATSH, Ethan (2004): "Bringing online dispute resolution to virtual worlds: creating processes through code", New York Law School Law Review, vol. XLIX, No 1: pp. 11011121.

Krausz Bitrán, Alan (2011): "La mano invisible del soft law en la protección del consumidor", en: Jornadas Chileno Uruguayas de Derecho Comercial (Santiago, Facultad de Derecho Universidad de Chile y Librotecnia) pp. 247-258.

León Hurtado, Avelino (1991): La voluntad y la capacidad en los actos jurídicos (Santiago, Editorial Jurídica de Chile).

López Santa María, Jorge (1998): Los contratos. Parte general (Santiago, Editorial Jurídica de Chile).

Mekki, Mustapha y Kloeper Pelese, Martine (2008): "Good faith and fair dealing in the DCFR”, European Review of Contract Law, vol. IV, No 3: pp. 338-374.

Peñailillo Arévalo, Daniel (1999): "La declaración unilateral de voluntad como fuente de obligaciones", Revista de Derecho de la Universidad de Concepción, vol. LXVII, No 206: pp. 7-23.

Peñailillo Arévalo, Daniel (2003): Obligaciones. Teoría general y clasificaciones. La resolución por incumplimiento (Santiago, Editorial Jurídica de Chile).

Perret, Louis (1999): "Protección al consumidor: en Canadá y Estados Unidos: principales técnicas”, en Corral Talciani, Hernán (coord.), Derecho del consumo y protección al consumidor (Santiago, Facultad de Derecho, Universidad de los Andes) pp. 15-24.

Pinochet Olave, Ruperto (2013): "Artículo 12A", en: De la Maza Gazmuri, Iñigo y Pizarro Wilson, Carlos (Dirs.) y Barrientos Camus, Francisca (Coord.), Comentarios a la Ley de Protección a los Derechos de los Consumidores. (Santiago, LegalPublishing y Thomson Reuters) pp. 265-282.

Pinochet Olave, Ruperto (2005): "La protección del contratante débil: doctrina de las expectativas razonables", Gaceta Jurídica, No 297: pp. 27-34.

Pinochet Olave, Ruperto (2001): "La recepción de la realidad de las nuevas tecnologías de la información por el Derecho Civil: Panorama actual y perspectivas futuras", Ius et Praxis, vol. VII, No 2: pp. 469-489.

Pinochet Olave, Ruperto (2007): Derecho Civil y nuevas tecnologías (Santiago, LexisNexis).

Pizarro Wilson, Carlos (2004): "Notas críticas sobre el fundamento de la fuerza obligatoria del contrato. Fuentes e interpretación del artículo 1545 del Código Civil chileno", Revista Chilena de Derecho, vol. 31, No 2: pp. 235-236.

Pizarro, Ramón Daniel y Vallespinos, Carlos Gustavo (1991): "Publicidad inductiva y engañosa", Derecho del Consumidor, No 1: pp. 41-47.

Rodríguez Grez, Pablo (2008): "Pacta sunt servanda", Revista Actualidad Jurídica de la Universidad del Desarrollo, vol. IX, No 18: pp. 107-187.

Ruz Lártiga, Gonzalo (2011): Explicaciones de Derecho civil: contratos y responsabilidad extracontractual (Santiago, LegalPublishing).

SaAvedra Galleguillos, Francisco Javier (1996): "El principio general de la buena fe", en Instituciones modernas de Derecho civil Homenaje al profesor Fernando Fueyo Laneri (Santiago, Editorial ConoSur) pp. 357-373. 
Sandoval López, Ricardo (2001): "Principios que informan al derecho del comercio electrónico", Revista de Derecho de la Universidad de Concepción, vol. LXIX, No 210: pp. 169-184.

Sandoval López, Ricardo (2004): Las reformas introducidas por la ley $N^{\circ} 19.955$ de 14 de julio de 2004 a la ley $N^{\circ} 19.496$, sobre protección de los derechos de los consumidores (Santiago, LexisNexis).

Segura Riveiro, Francisco (2010): "La buena fe, un aspecto de tensión entre los sistemas jurídicos”, en Estudios de Derecho civil (Santiago, Albeledo Perrot y LegalPublishing) pp. 499-510.

Somarriva Undurraga, Manuel (1934): "Algunas consideraciones sobre el principio de la autonomía de la voluntad”, Revista de Derecho, Jurisprudencia y Ciencias Sociales, vol. XXXI, No 37: pp. 17-27.

Tapia Rodríguez, Mauricio y Valdivia Olivares, José Miguel (2002): Contratos por adhesión. Ley No 19.496 (Santiago, Editorial Jurídica de Chile) pp. 83-84.

VIAL Del Río, Víctor (2003): Teoría general del acto jurídico (Santiago, Editorial Jurídica de Chile).

Vidal Olivares, Álvaro (2010): "Contratación y consumo el contrato de consumo en la Ley N 19.496 sobre protección a los derechos de los consumidores", Revista de Derecho de la Pontificia Universidad Católica de Valparaíso, No 21: pp. 229-255. 